\title{
Peningkatan Kemampuan Berbicara Dengan Metode Two Stay Two Stray Pada Siswa Kelas Xi Bahasa Ma Muallimat NW Pancor Tahun 2018.
}

\author{
Muh. Roni Hidayatullah \\ Intstitut Pendidikan Nusantara Global \\ ronihidayatullah@nusantaraglobal.ac.id
}

\begin{abstract}
Abstrak:: Penelitian ini bertujuan untuk: (1) Mendeskripsikan proses pembelajaran bahasa Indonesia bidang berbicara, (2) Mengetahui peningkatan kemampuan berbicara siswa dalam pembelajaran bahasa Indonesia. Penelitian ini merupakan penelitian tindakan kelas. Data dalam penelitian ini bersumber dari siwa kelas XI Bahasa MA.Muallimat NW Pancor. Metode yang digunakan dalam penelitian ini adalah metode Two Stay Two Stray (Dua Tinggal Dua Tamu). Hasil penelitian ini adalah; (1) Proses pembelajaran bahasa Indonesia dengan metode Two Stay Two Stray (Dua Tinggal Dua Tamu)" padasiswa kelas XI BahasaMA.Muallimat NW Pancor dapat di lihat pada kegitan siswa yang sangat aktif dan antusias.(2)Peningkatan Kemampuan berbicara siswa dilihat juga dari hasil belajar siswa dalam mengikuti proses pembelajaran dengan serius, menyimak, dan mendengarkan penjelasan guru, selalu bertanya dan menjawab soal-soal yang diberikan dalam diskusi kelompok.
\end{abstract}

Kata Kunci : Berbicara, Metode, Siswa

\section{PENDAHULUAN}

Upaya peningkatan kualitas pendidikan hingga dewasa ini masih merupakan kegiatan yang terus digalakkan. Hal ini tidak saja disebabkan oleh tuntutan laju perkembangan ilmu pengetahuan dan teknologi. Akan tetapi, ini juga tuntutan profesionalisme dalam berbagai sektor pendidikan.

Peningkatan mutu dan relevansi pendidikan sesuai kebutuhan masyarakat yang sangat erat kaitannya dengan pengembangan SDM (Sumber Daya Manusia), sehingga pemerintah telah banyak berupaya agar semua ini dapat tercapai.

Hal tersebut dapat terlihat dari perubahan dan perbaikan kurikulum, metode, dan pendekatan yang digunakan dalam pembelajaran saat ini.

Masalah yang melatar belakangi penelitian ini adalah kurangnya kemampun berbicara siswa dalam berdiskusi,tidak percaya diri, sehingga pendapat yang ada dalam pikirannya tidak berani dikeluarkan, selain itu juga takut salah dan takut ditertawakan yang membuat para siswa enggan berbicara atau menjawab pertanyaan yang dilontarkan oleh gurunya. Sering juga kita melihat di dalam kelas, ketika seorang siswa menjawab pertanyaan, kemudian salah maka siswa yang lain mentertawakannya.

Tindakan peneliti dalam penyelsaian masalah ini adalah menawarkan proses pembelajaran yang lebih kreatif dan menyenangkan yaitu dengan metode Two Stay Two Stray.

Menurut Rakhmat (2011:2), kemampuan berbicara bukan saja diperlukan di depan sidang parlemen, di muka hakim atau di hadapan massa. Kemampuan ini dihajatkan dalam hampir seluruh kegiatan manusia sehari-hari. Penelitian membuktikan bahwa $75 \%$ waktu bangun kita berada dalam kegiatan komunikasi.

Menurut Nurjamal dkk (2011:23), berbicara sebagai suatu keterampilan, hanya akan dimiliki-dikuasai seseorang apabila dia mau berlatih. Tidak ada satu pun keterampilan yang dapat dikuasai seseorang tanpa adanya proses pelatihan yang terus-menerus. Untuk terampil berbicar itu pun mari kita berlatih dan terus berlatih.

Menurut Suprijono (2009:93-94), metode Dua Tinggal Dua Tamu mrupakan sebuah metode yang diawali dengan pembagian kelompok. Setelah kelompok dibentuk guru memberikan tugas berupa permasalahanpermasalahan yang harus mereka diskusikan 
jawabannya. Setelah diskusi intrakelompok usai, dua orang dari masing-masing kelompok meninggalkan kelompoknya untuk bertamu kepada kelompok yang lain. Anggota kelompok yang tidak mendapat tugas sebagai duta (tamu) mempunyai kewajiban menerima tamu dari suatu kelompok. Tugas mereka adalah menyajikan hasil kerja kelompoknya kepada tamu tersebut. Dua orang yang bertugas sebagai tamu diwajibkan bertamu kepada semua kelompok. Jika mereka telah usai menunaikan tugasnya, mereka kembali ke kelompoknya masing-masing. Setelah kembali ke kelompok asal, baik peserta didik yang bertugas bertamu maupun mereka yang bertugas menerima tamu mencocokkan dan membahas hasil kerja yang telah mereka tunaikan.

\section{METODE PENELITIAN}

Jenis penelitian ini adalah Penelitian Tindakan Kelas (Classrom Action Research) dengan menerapkan model pembelajaran kooperatife metode Two Stay Two Stray (Dua Tinggal Dua Tamu). Penelitian tindakan kelas merupakan pencermatan terhadap kegiatan yang sengaja dimunculkan, dan terjadi dalam sebuah kelas (Aqib: 2006: 12).

Rancangan untuk tiap siklus pada penelitian tindakan kelas ini sebagaimana menurut Arikunto (2010:131), model yang dikembangkan oleh Kurt Lewin didasarkan atas konsep pokok bahwa penelitian tindakan terdiri dari empat komponen pokok yang juga menunjukkan langkah, yaitu perencanaan (planning), aksi/tindakan (acting), observasi/pengamatan (obseving), dan refleksi (refleting). Hubungan antara empat komponen tersebut menunjukkan sebuah siklus atau kegiatan berulang. "Siklus" inilah yang sebetulnya menjadi salah satu ciri utama dari penelitian tindakan, yaitu bahwa penelitian tindakan harus dilaksanakan dalam bentuk siklus, bukan hanya satu kali intervensi saja.

Dalam penelitian ini yang menjadi subjek penelitian adalah siswa kelas XI Bahasa MA.Muallimat NW Pancor Kec. Selong Kabupaten Lombok Timur Tahun Pembelajaran 2018/2019.

\section{Prosedur Penelitian}

Menurut Arikunto (2010:131), penelitian tindakan kelas (PTK) mengandung empat kegiatan utama yang ada pada setiap siklus yaitu: tahap perencanaan, tahap pelaksanaan tindakan, tahap observasi dan tahap refleksi. Penelitian ini merupakan penelitian tindakan kelas (PTK), di mana penelitian ini direncanakan terdiri dari dua siklus, namun bila hasil belum mencapai target, akan dilaksanakan siklus selanjutnya. Setiap siklus terdiri atas empat tahapan rangkaian yang dilakukan berulang-ulang. Penelitian tindakan kelas mengandung empat kegiatan utama. Berikut rincian kegiatan pada setiap tahap adalah sebagai berikut:

\section{Siklus I}

a. Tahap Perencanaan

Pada tahap perencanaan ini peneliti melakukan sebuah kegiatan. kegiatan yang dilakukan adalah (1) mempelajari kurikulum, (2)membuat RPP dengan menggunakan Metode Dua Tinggal Dua Tamu, (3) menyusun lembar observasi pelaksanaan pembelajaran (tindakan guru) untuk mengetahui bagaimana pelaksanaan Metode Dua Tinggal Dua Tamu dapat dilaksanakan, (4) merumuskan indikator kemampuan berbicara siswa (lembar observasi siswa) untuk mengetahui tingkat perkembangan berbicara siswa pada setiap siklus kegiatan.

b. Tahap Pelaksanaan Tindakan

Pada tahap pelaksanaan tindakan ini, guru (peneliti) menerapkan pembelajaran di kelas yakni dengan Metode Dua Tinggal Dua Тати, sesuai dengan rencana program yang telah disusun, yaitu terdiri atas pendahuluan, kegiatan inti, dan penutup.

c. Tahap Observasi

Pada tahap ini, dilakukan observasi terhadap pelaksanaan tindakan dengan menggunakan lembar observasi, di mana pada tahap ini siswa diobservasi oleh peneliti dan guru bidang studi.

\section{d. Tahap Refleksi}

Tahap refleksi merupakan tahapan pemerosesan data yang diperoleh dari tahap observasi. Data yang diperoleh kemudian ditafsirkan dan dijadikan masukan pada analisis data dengan mempertimbangkan 
bahwa segala pengalaman teori dan pengalaman instruksional direfleksi untuk menarik suatu kesimpulan.

\section{Siklus II \\ Perencanaan Tindakan}

Pada tahap perencanaan tindakan ini ada beberapa instrument yang disiapkan, antara lain; 1) membuat rencana pembelajaran, 2) menentukan materi yang akan dibahas, 3) menyusun lembar observasi, dan 4) menyusun tes / soal evaluasi hasil belajar.

\section{Pelaksanaan Tindakan}

Secara operasional langkah-langkah pelaksanaannya adalah sebagai berikut:

\section{Pendahuluan}

Hal-hal yang dilakukan dalam pendahuluan sebagai berikut;

1.1 Memberikan apersepsi kehadiran siswa

1.2 Menyampaikan topik dan tujuan pembelajaran

1.3 Menjelaskan kepada siswa langkahlangkah metode Two Stay Two Stray (Dua Tinggal Dua Tamu)

\section{Kegiataan inti}

2.1 Guru memberikan pemahaman tentang materi berita dan bagaimana penyampaian berita yang benar

2.2 Siswa membaca secara intensif contoh berita yang tersaji dalam buku teks

2.3 Siswa mengidentifikasi masalahmasalah penting dalam teks dan merumuskannya ke dalam berberapa kalimat tanya yang akan dibahas pada diskusi kelompok

2.4 Guru dan siswa membuat sebuah kelompok yang terdiri dari 4 orang siswa dalam 1 kelompok

2.5 Guru memberikan masalah yang akan dibahas dalam diskusi atau soal evaluasi ke-2 pada siklus II ini

\section{Penutup}

Menyimpulkan hasil kegiatan pembelajaran.

\section{Observasi dan evaluasi}

Kegiatan observasi dan evaluasi yang dilakukan sama seperti kegitan observasi dan evaluasi pada siklus I. hal-hal yang terjadi selama berlangsungnya pembelajaran terkait dengan pelaksanaan tindakan dicatat dalam lembar observasi.

Refleksi

Dilakukan refleksi terhadap tindakan yang telah dilakukan berdasarkan hasil observasi pada siklus II ini, untuk mengetahui berhasil tidaknya pemberian tindakan. Dalam refleksi ini dianalisis semua kegiatan yang dilakukan oleh siswa untuk dijadikan data verbal dan data nonverbal.

\section{Teknik Pengumpulan Data}

Pengumpulan data yang dilakukan dalam penelitian tindakan kelas ini adalah:

\section{Observasi}

Observasi merupakan cara mengumpulkan data berdasarkan pengamatan yang berlangsung pada saat proses pembelajaran dengan menggunakan lembar observasi aktifitas belajar siswa dan guru, semua ini bertujuan untuk memperbaiki kekurangankekurangan yang ditemukan dalam proses pembelajaran bahasa Indonesia kelas XI BahasaMA.Muallimat NW Pancor.

\section{Tes}

Menurut Arikunto (2010:193), tes merupakan serentetan pertanyaan atau latihan serta alat lain yang digunakan untuk mengukur keterampilan, pengetahuan interlegensi, kemampuan atau bakat yang dimiliki oleh individu atau kelompok. Pengumpulan data dengan tes lisan yang berbentuk diskusi kelompok ini merupakan kegiatan atau usaha yang dilakukan untuk mengetahui sejauh mana hasil belajar siswa dengan metode Two Stay Two Stray (Dua Tinggal Dua Taтu) dalam pembelajaran bahasa Indonesia.

\section{Teknik Analisis Data}

Teknik penganalisisan data dalam penelitian ini ada dua macam, yaitu deskriptif kualitatif dan deskriptif kuantitatif. Data yang dianalisis dengan deskriptif kualitatif yaitu data yang bersifat verbal, yang menggambarkan tingkahlaku siswa, aktifitas siswa, dan antusias siswa dalam proses pembelajaran. Sedangkan data yang dianalisis dengan deskriptif kuantitatif yaitu data yang berbentuk nominal/non-verbal, yang 
menggambarkan hasil belajar siswa dengan tes.

Hasil belajar yang diperoleh siswa dianalisis secara deskriptif kuantitatif dengan mencari nilai rata-rata kelas dan ketuntasan belajar.

\section{Menghitung Nilai Rata-Rata}

Setelah diperoleh data hasil evaluasi, nilai rata-rata kelas dihitung dari skor ratarata tes tiap siklus dengan rumus:

$$
\boldsymbol{M}=\frac{\sum \mathbf{x}}{\mathbf{N}}
$$

Keterangan :

$$
\begin{array}{ll}
\mathrm{M} & \text { : mean (rata-rata) } \\
\sum_{\mathrm{N}} x & \text { : jumlah skor keseluruhan siswa } \\
\mathrm{N} & \text { : jumlah siswa }
\end{array}
$$

\section{Menghitung Nilai Ketuntasan Belajar}

Ketuntasan belajar minimal $75 \%$ siswa mendapat nilai $\geq 75$ secara individual. Jika pada siklus I hasil yang diperoleh tidak mencapai ketuntasan belajar, yaitu minimal $75 \%$ siswa memperoleh nilai $\geq 75$ maka dilanjutkan ke siklus berikutnya hingga mencapai ketuntasan belajar. Adapun rumus yang digunakan untuk mengetahui ketuntasan belajar adalah:

$$
K B=\frac{N I}{N} x 100 \%
$$

Keterangan :

KB : ketuntasan belajar

NI : banyak siswa yang memperoleh nilai $\geq 75$

$\mathrm{N}$ : banyak siswa

Ketuntasan belajar dikatakan tercapai jika $\mathrm{KB} \geq 75 \%$ dan jika $\mathrm{KB}$ $\leq 75 \%$ maka ketuntasan belajar belum dikatakan tercapai atau belum tuntas.

\section{Indikator Keberhasilan}

Keberhasilan siswa di dalam keterampilan berbicara akan ditentukan oleh jumlah hasil penilaian dari beberapa aspek yang dinilai, dan siswa dapat dikatakan mencapai keberhasilan apabila memperoleh jumlah nila $\geq 75$ setelah penjumlahan dari ke enam aspek penilaian yang sudah ditentukan.

Indikator keberhasilan itu juga dilihat dari meningkatnya motivasi, keinginan, antusias siswa, dan keaktifan siswa dalam

\begin{tabular}{|c|c|c|}
\hline NO & Aspek Penilaian & $\begin{array}{c}\text { Skor } \\
\text { Maksimal }\end{array}$ \\
\hline 1 & Ketepatan Ucapan & 20 \\
\hline 2 & Diksi & 15 \\
\hline 3 & Penguasaan Topik & 20 \\
\hline 4 & Struktur Isi & 20 \\
\hline 5 & Gerak-gerik dan Mimik & 15 \\
\hline 6 & Volume Suara & 10 \\
\hline & Jumlah & 100 \\
\hline
\end{tabular}

proses pembelajaran bahasa Indonesia yang diterapkan dengan metode Two Stay Two Stray (Dua Tinggal Dua Tamu) pada siswa

\begin{tabular}{|c|c|c|c|c|}
\hline $\mathrm{N}$ & Penilaian & Skor & Kriteria & Kategori \\
\hline \multirow[t]{3}{*}{1} & \multirow{3}{*}{$\begin{array}{l}\text { Ketepatan } \\
\text { ucapan }\end{array}$} & 20 & $\begin{array}{l}\text { Jika bunyi bahasa meliputi } \\
\text { artikulasi yang tepat }\end{array}$ & $\begin{array}{l}\text { Sangat } \\
\text { baik }\end{array}$ \\
\hline & & 15 & $\begin{array}{l}\text { Jika bunyi bahasa meliputi } \\
\text { sebagian artikulasi }\end{array}$ & Baik \\
\hline & & 10 & $\begin{array}{l}\text { Bunyi bahasa tidak tepat } \\
\text { dan tidak jelas }\end{array}$ & Kurang \\
\hline \multirow[t]{3}{*}{2} & \multirow[t]{3}{*}{ Diksi } & 15 & $\begin{array}{l}\text { Jika diksi sesuai dengan } \\
\text { pokok pembicaraan dan } \\
\text { situasi }\end{array}$ & Baik \\
\hline & & 10 & $\begin{array}{l}\text { Apabila ada terdapat kata- } \\
\text { kata sulit/istilah }\end{array}$ & $\begin{array}{l}\text { Cukup } \\
\text { baik }\end{array}$ \\
\hline & & 5 & $\begin{array}{l}\text { Jika diksi tidak sesuai } \\
\text { dengan pokok pembicaraan } \\
\text { dan terdapat makna } \\
\text { ambigu }\end{array}$ & Kurang \\
\hline \multirow[t]{3}{*}{3} & \multirow[t]{3}{*}{$\begin{array}{l}\text { Penguasaan } \\
\text { Topik }\end{array}$} & 20 & $\begin{array}{l}\text { Jika topik pembicaraan } \\
\text { benar-benar dikuasai }\end{array}$ & $\begin{array}{l}\text { Sangat } \\
\text { baik }\end{array}$ \\
\hline & & 15 & $\begin{array}{l}\text { Topik pembicaraan kurang } \\
\text { dipahami }\end{array}$ & Baik \\
\hline & & 5 & $\begin{array}{l}\text { Jika topik pembicaraan } \\
\text { tidak dikuasai dan kurang } \\
\text { pengalaman }\end{array}$ & Kurang \\
\hline \multirow[t]{3}{*}{4} & \multirow[t]{3}{*}{ Struktur isi } & 20 & $\begin{array}{l}\text { Jika terdiri dari } \\
\text { pendahuluan, isi, dan } \\
\text { penutup }\end{array}$ & Baik \\
\hline & & 15 & $\begin{array}{l}\text { Apabila terdiri } \\
\text { pendahuluan dan isi saja }\end{array}$ & $\begin{array}{l}\text { Cukup } \\
\text { baik }\end{array}$ \\
\hline & & 5 & $\begin{array}{l}\text { Jika terdiri pendahuluan } \\
\text { dan penutup saja. }\end{array}$ & kurang \\
\hline \multirow[t]{3}{*}{5} & \multirow[t]{3}{*}{$\begin{array}{l}\text { Gerak-gerik } \\
\text { dan mimic }\end{array}$} & 15 & $\begin{array}{l}\text { Jika penyampaian materi } \\
\text { didukung dengan gerakan } \\
\text { tangan dan mimic }\end{array}$ & Baik \\
\hline & & 10 & $\begin{array}{l}\text { Jika penyampaian materi } \\
\text { kurang dihayati tapi } \\
\text { diiringin dengan gerakan }\end{array}$ & Cukup \\
\hline & & 5 & $\begin{array}{l}\text { Apabila penyampaian } \\
\text { materi kaku dan tidak ada } \\
\text { gerak-gerik }\end{array}$ & Kurang \\
\hline \multirow[t]{2}{*}{6} & \multirow[t]{2}{*}{$\begin{array}{l}\text { Volume } \\
\text { Suara }\end{array}$} & 10 & $\begin{array}{l}\text { Jika tinggi rendahnya suara } \\
\text { disesuaikan dengan situasi } \\
\text { atau keadaan }\end{array}$ & Baik \\
\hline & & 5 & $\begin{array}{l}\text { Apabila tinggi rendahnya } \\
\text { suara tidak teratur }\end{array}$ & Kurang \\
\hline
\end{tabular}
kelas XI BahasaMA.Muallimat NW Pancor Tahun Pembelajaran 2018-2019.

\section{Tabel Skor Penilaian}

Tabel Kriteria dan Kategori Aspek Penilaian 


\section{HASIL DAN PEMBAHASAN \\ Deskripsi Data}

Penelitian Tindakan Kelas (PTK) ini dilakukan untuk meningkatkan kemampuan berbicara denganmetode Two Stay Tow Stray (Dua Tinggal Dua Taтu) Pada Siswa Kelas XI Bahasa MA.Muallimat NW Pancor Tahun Pembelajaran 2018-2019.

Penelitian ini berhasil dilihat daru peningkatan nilai rata-rata pada siklus I ke tahapan siklus II dan ketuntasan belajar siswa minimal $75 \%$ mendapat nilai $\geq 75$. Penelitian ini dilaksanakan dalam 2 siklus dengan melibatkan 28 siswa/siswi yang bertindak sebagai subjek penelitian.

Data hasil penelitian yang diperoleh dapat diuraikan sebagai berikut:

\section{Data Siklus I}

\section{Data bersifat verbal}

1). Hasil observasi kegiatan guru

Kegiatan yang dilaksanakan oleh guru adalah menyiapkan RPP, penyajian materi tidak menyimpang dari pembahasan, pendampingan selama pembelajaran terkontrol, dan menerapkan metode yang sudah ditetapkan. Dalam kegiatan ini, masih ada kekurangan yang ditemukan yaitu;

a) Guru kurang memberi apersepsi di awal pembelajaran

b) Guru kurang mampu membuat suasana kelas yang kondusif terlihat dari masih banyak siswa yang tidak aktif di dalam berbicara, menyampaikan pertanyaan atau pun pendapat.

c) Guru lebih dominan dalam menyimpulkan hasil pembelajaran.

2) Hasil observasi kegiatan siswa

Sebagian siswa sudah melaksanakan program/kegiatan yang sudah disediakan oleh peneliti, diantaranya siswa mengikuti pembelajaran dengan baik, melaksanakan langkah-langkah metode Two Stay Two Stray, dan mendengar penjelasan dari guru. Namun, masih ada juga siswa yang kesiapannya dalam mengikuti pembelajaran masih kurang, tidak antusias mengikuti proses pembelajaran, dan masih malu mengajukan pertanyaan dan jawaban terhadap teman-teman kelompoknya.

\section{Data bersifat non-verbal}

Data ini diperoleh dari hasil nilai tes yang diberikan kepada siswa untuk mengukur kemampuan berbicara yang berdasarkan enam (6) aspek penilaian yaitu, ketepatan ucapan, diksi, penguasaan topik, struktur isi, gerak-gerik/mimik, dan volume suara.

\section{Analisis data pada Siklus I}

1. Menghitung nilai rata-rata siswa

Berdasarkan skor hasil pada data di atas nilai tertinggi pada siklus I yang diperoleh siswa adalah 85 dan skor terendah 65 . Sedangkan jumlah skor nilai yang diperoleh seluruh siswa: 2050 dari jumlah siswa 28 orang, untuk mengetahui nilai rata-rata siswa dapat digunakan rumus sebagai berikut;

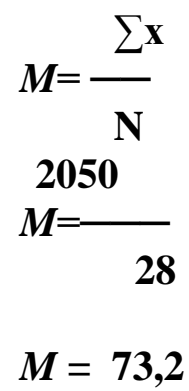

Jadi, nilai rata-rata siswa pada siklus I adalah 73,2

2. Menghitung Ketuntasan Belajar siswa

Dalam siklus I ini, banyak siswa yang memperoleh nilai $\geq 75$ adalah 15 orang, dan banyak siswa yang mengikuti tes adalah 28 orang. Untuk mengetahui ketuntasan belajar siswa dapat digunakan rumus sebagai berikut;

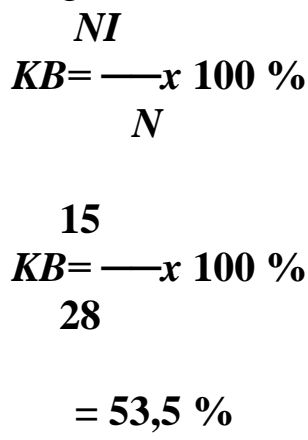

Jadi, ketuntasan belajar siswa pada siklus I adalah 53,5 \%

Ketuntasan belajar dikatakan tercapai jika $\mathrm{KB} \geq 75 \%$ yang mendapat nilai $\geq 75$. Melihat ketuntasan hasil belajar pada siklus I sebanyak 53,5\% yang mendapat $\geq 75$ maka, belum dikatakan tuntas belajar, untuk itu diperlukan siklus berikutnya yaitu siklus II.

\section{Data Siklus II}

a. Data bersifat verbal

1) Hasil observasi kegiatan guru

Kegiatan yang dilaksanakan oleh guru adalah menyiapkan RPP, penyajian materi 
sesuai dengan pembahasan/topik pembicaraan, pendampingan selama pembelajaran terkontrol, dan menerapkan metode two stay two stray (dua tinggal dua tamu) dengan maksimal, memberikan apersepsi di awal pembelajaran, guru membuat suasana kelas yang kondusif terlihat dari banyak siswa yang aktif di dalam berbicara, menyampaikan pertanyaan atau pun berpendapat untuk memcahkan masalah. Jadi guru sudah melaksanakan tugas secara maksimal yang mendorong motivasi dan semangat belajar siswa sehingga mendapat hasil yang memuaskan.

2) Hasil observasi kegiatan siswa

Dalam tahap ini, siswa melaksanakan program/kegiatan yang disediakan oleh peneliti dengan baik, diantaranya siswa mengikuti pembelajaran dengan serius, melaksanakan langkah-langkah metode Two Stay Two Straydengan tertib, dan pokus dalam mendengarkan penjelasan dari guru/peneliti.

Dari hasil observasi ini, kesiapan siswa dalam proses pembelajaran sudah maksimal, karena dalam diri siswa sudah timbul semangat belajar yang tinggi, antusias mengikuti proses pembelajaran, dan tidak malu lagi mengajukan pertanyaan dan jawaban terhadap teman-teman kelompoknya. Sehingga pada tahapan ini siswa memproleh nilai rata-rata yang maksimal, sesuai dengan target keberhasilan pada penelitian ini.

Data bersifat non-verbal/angka

Nilai ini diperoleh dari hasil nilai tes yang ke-2, yang diberikan kepada siswa bertujuan untuk mengukur kemampuan berbicara yang berdasarkan enam (6) aspek penilaian yaitu, ketepatan ucapan, diksi, penguasaan topik, struktur isi, gerakgerik/mimik, dan volume suara.

Dari hasil penilaian pada siklus II ini, masih ada beberapa siswa yang tidak tuntas, karena untuk memproleh hasil yang maksimal membutuhkan waktu yang panjang dalam mendidik, dan memberikan pembelajaran. Akan tetapi, dalam penelitian ini sudah bisa dikatakan berhasil karena sudah memenuhi target ketuntasan yang ditentukan yaitu jika $\mathrm{kb} \geq 75 \%$ siswa mendapat $\geq 75$ maka dikatakan tuntas.

\section{PEMBAHASAN}

Pada pembahasan ini, peneliti akan menguraikan hasil penelitian yang telah dilakukan.

Keberhasilan dalam proses pembelajaran bahasa Indonesia dengan metode Two Stay Two Stray (Dua Tinggal Dua Tamu)" padasiswa kelas XI Bahasa MA.Muallimat NW Pancor dapat di lihat pada kegiatan peneliti (guru), dan kegitan siswa. Dalam kegiatan penelitian ini, sebelum peneliti mulai mengajar terlebih dahulu menyusun perangkat pembelajaran diantaranya menyiapkan silabus, menyusun RPP menggunakan metode Two Stay Two Stray, menyampaikan materi sesuai dengan pembahasan, memberi pemahaman sekilas tentang keterampilan berbicara, menjelaskan langkah-langkah metode yang akan diterapkan, dan memahami karakter siswa.

Adapun kegiatan siswa yang bisa dipaparkan peneliti adalah mengikuti proses pembelajaran dengan serius, menyimak, dan mendengarkan penjelasan guru, antusias dalam bertanya dan menjawab soal-soal yang diberikan dalam diskusi kelompok, dan menerapkan langkah-langkah metode Two Stay Two Stray (Dua Tinggal Dua Tamu).

Adapun peningkatan hasil belajar siswa dalam penelitian ini dapat dilihat pada tabel di bawah ini.

Tabel Ringkasa hasil siklus I dan siklus II

\begin{tabular}{|c|c|c|}
\hline Siklus & $\begin{array}{c}\text { Nilai Rata-rata } \\
\text { Prestasi Siswa }\end{array}$ & $\begin{array}{c}\text { Ketuntasan } \\
\text { Belajar Siswa }\end{array}$ \\
\hline I & 73,2 & $53,5 \%$ \\
\hline II & 82,14 & $92,85 \%$ \\
\hline
\end{tabular}

\section{Simpulan}

Berdasarkan penelitian dan pembahasan p sebelumnya dapat disimpulkan bahwa:

1) Kemampuan berbicara siswa kelas XI BahasaMA.Muallimat NW Pancortergolong dalam kategori baik setelah menggunakan metode Two Stay Two Stray dalam proses pembelajaran bahasa Indonesia. Hal ini dapat dilihat 
pada siklus I dan siklus II dengan nilai rata-rata yang diperoleh siswa.

2) Peningkatan kemampuan berbicara pada siswa kelas XIMA.Muallimat NW Pancor termasuk dalam kategori baik. Peningkatan ini dapat dilihat dari hasil mean dan tingkat keberhasilan yang diperoleh siswa yaitu pada siklus I meannya $73,2 \%$, dan tingkat keberhasilan juga mencapai 53,5 \% dan dapat ditingkatkan pada siklus II dengan mean 82,14 dan tingkat keberhasilan atau ketuntasa belajar siswa mencapai 92,85\%.

\section{DAFTAR PUSTAKA}

Aqib, Zainal. 2006. Penelitian Tindakan Kelas untuk Guru. Bandung: Yrama Widya.

Arikunto, Suharsimi. 2010. Prosedur Penelitian Suatu Pendekatan Praktik (Edisi Revisi 2010). Jakarta: Rineka Cipta.

Nurjamal, Daeng dkk. 2011. Terampil Berbahasa. Bandung: Alfabeta.

Rakhmat, Jalaludin. 2008. Retorika Moderen Pendekatan Praktis. Bandung: Remaja Rosdakarya.

Suprijono, Agus. 2009. Cooperative Leraning. Surabaya: Pustaka Pelajar 